\title{
Substantia Nigra and Parkinson's Disease: A Brief History of Their Long and Intimate Relationship
}

\author{
Martin Parent, André Parent
}

\begin{abstract}
The substantia nigra was discovered in 1786 by Félix Vicq d'Azyr, but it took more than a century before Paul Blocq and Georges Marinesco alluded to a possible link between this structure and Parkinson's disease. The insight came from the study of a tuberculosis patient admitted in Charcot's neurology ward at la Salpêtrière because he was suffering from unilateral parkinsonian tremor. At autopsy, Blocq and Marinesco discovered an encapsulated tumor confined to the substantia nigra, contralateral to the affected side, and concluded that tremor in that particular case resulted from a midbrain lesion. This pioneering work, published in 1893, led Edouard Brissaud to formulate, in 1895, the hypothesis that the substantia nigra is the major pathological site in Parkinson's disease. Brissaud's hypothesis was validated in 1919 by Constantin Trétiakoff in a remarkable thesis summarizing a post-mortem study of the substantia nigra conducted in Marinesco's laboratory. Despite highly convincing evidence of nigral cell losses in idiopathic and post-encephalitic Parkinsonism, Trétiakoff's work raised considerable doubts among his colleagues, who believed that the striatum and pallidum were the preferential targets of parkinsonian degeneration. Trétiakoff's results were nevertheless confirmed by detailed neuropathological studies undertaken in the 1930s and by the discovery, in the 1960s, of the dopaminergic nature of the nigrostriatal neurons that degenerate in Parkinson's disease. These findings have strengthened the link between the substantia nigra and Parkinson's disease, but modern research has uncovered the multifaceted nature of this neurodegenerative disorder by identifying other brain structures and chemospecifc systems involved in its pathogenesis.
\end{abstract}

RÉSUMÉ: Aperçu historique de la relation entre la substance noire et la maladie de Parkinson. Bien que la substance noire ait été découverte en 1786 par Félix Vicq d'Azyr, ce n'est qu'un siècle plus tard que le pathologiste Paul Blocq et le neurologue Georges Marinesco firent une première allusion à une relation possible entre cette structure et la maladie de Parkinson. Cette proposition est venue de l'étude d'un patient tuberculeux admis à la clinique de neurologie de Charcot à la Salpêtrière parce qu'il présentait des tremblements unilatéraux de type parkinsonien. À l'autopsie, une tumeur encapsulée détruisant la substance noire controlatérale au côté affecté fut découverte et Blocq et Marinesco conclurent que les tremblements n'étaient pas symptomatiques d'une maladie de Parkinson mais plutôt le résultat de cette lésion mésencéphalique tumorale. Ce travail conduisit Edouard Brissaud à émettre, en 1895, l'hypothèse que la substance noire est le site lésionnel préférentiel dans la maladie de Parkinson. Cependant, c'est Constantin Trétiakoff qui valida cette hypothèse dans une remarquable thèse publiée en 1919 qui démontrait d'une façon très convaincante la perte des neurones de la substance noire dans de nombreux cas de maladie de Parkinson et de Parkinsonisme post-encéphalitique. Les résultats de Trétiakoff furent mis en doute par ses collègues, qui ne pouvaient accepter l'idée qu'une structure aussi petite que la substance noire soit responsable de troubles moteurs aussi marqués que ceux qui caractérisent la maladie de Parkinson. Il faudra attendre la contribution du neurologue allemand Rolf Hassler en 1938 pour que l'on réalise progressivement à quel point la substance noire et la maladie de Parkinson sont intimement liées.

Can. J. Neurol. Sci. 2010; 37: 313-319

The major pathological hallmark of Parkinson's disease is a massive neuronal loss that occurs at the level of a relatively small and darkly pigmented brainstem structure known today as the substantia nigra. The intimate relationship between this structure and the devastating psychomotor disorder (Figure 1A), first described by James Parkinson in $1817,{ }^{1}$ took more than two centuries to unfold. The history began at the Age of the Enlightenment and, as is often the case, with an imbroglio regarding the paternity of a crucial finding.

\section{The substantia nigra at the Age of the Enlightenment}

The discovery of the substantia nigra has long been attributed to the great German scientist and philosopher Samuel Thomas von Sœmmerring (1755-1830), who provided original descriptions of various brain structures and the first accurate classification of cranial nerves that appeared in his 1778 treatise entitled De basi encephali. ${ }^{2}$ Most neuroanatomy textbooks published during the 19th and the first half of the 20th century referred to the substantia nigra as Scmmerring's substance, substantia nigra of Sœmmerring or locus niger Sommerringii,

From the Department of Psychiatry and Neuroscience, Laval University School of Medicine, Quebec City, Quebec, Canada.

Received September 28, 2009. Final Revisions Submitted November 19, 2009. Correspondence to: André Parent, Centre de Recherche Université Laval RobertGiffard, 2160, Chemin de la Canardière, Beauport, Québec, G1J 2G3, Canada. 


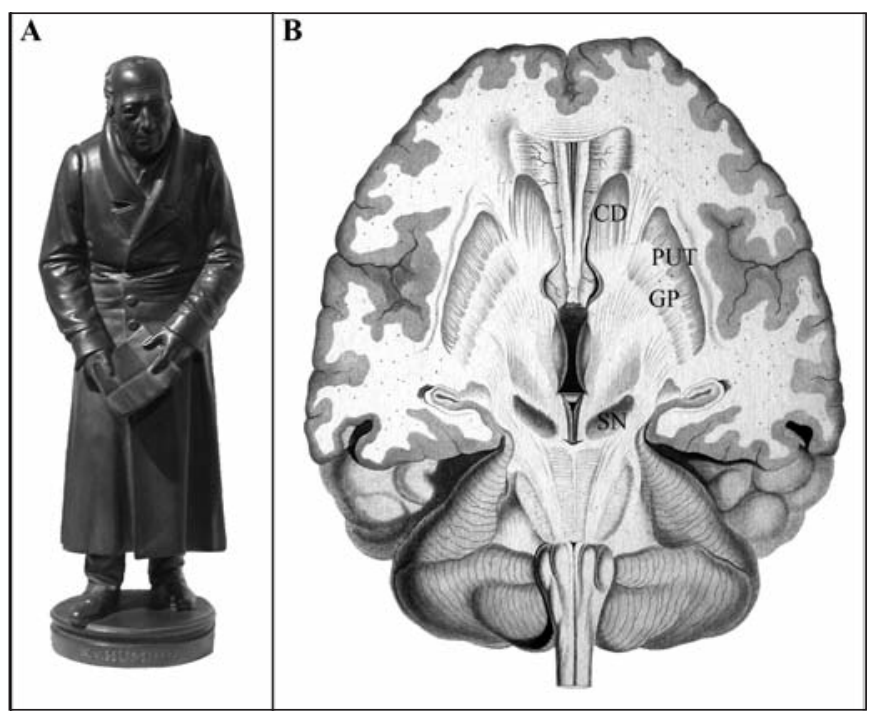

Figure 1: Parkinson's disease and substantia nigra. A: Photograph of a statuette of Wilhelm von Humboldt (1767-1835), the famous German philosopher, linguist and diplomat, sculpted by Johann Friedrich Drake (1805-1882) in 1834. It emphasizes the hunched posture, flexed arms and masklike face of von Humboldt, who suffered from Parkinson's disease since about 1820. This statuette antedates by several decades the classic figurine of Paul Richer (1849-1933), a former student of Charcot at la Salpêtrière. B: Reproduction of a figure (plate XXII) from Vicq d'Azyr F. Traité d'anatomie et de physiologie. Paris: Didot, 1786. It depicts, for the first time, the substantia nigra (SN), as it appears in a horizontal section of a human brain. The putamen (PUT), caudate nucleus (CD) and globus pallidus $(G P)$ are also well delineated in this figure. Current abbreviations for these basal ganglia components have been added onto the original plate, which was drawn and engraved by Alexandre Briceau with a combination of aquatint, line-engraving and stipple-engraving.

but Sœmmerring himself did not mention the existence of the substantia nigra in his 1778 treatise. It is only in a revised version of his work published in $1792^{3}$ that he alluded to this structure recognizing that it was formally identified and illustrated by the French anatomist Félix Vicq d'Azyr (1748-1794).4,5 Like von Sœmmerring, Vicq d'Azyr was a typical medical figure of the Age of the Enlightenment; he had a vast and deep knowledge of medicine and biology that encompassed several fields of investigation, including epidemiology, comparative anatomy, social medicine and neurology. ${ }^{6}$ He was one of the founders of the Royal Academy of Medicine and he remained the perpetual secretary of this prestigious institution until it was abolished by the French revolutionaries in 1793. His most enduring contribution to human brain anatomy was a remarkable work entitled Traité d'anatomie et de physiologie published in $1786 .^{7}$ This large folio volume contained 35 nature-sized, colored, human brain figures of a quality and exactitude never attained before. The substantia nigra was clearly outlined in two of these magnificent illustrations (Figure 1B). Vick d'Azyr noted the dark pigmented nature of this structure that he aptly called tache noirâtre or locus niger crurum cerebri. Vick d'Azyr's treatise was to be the first of a long series of books designed to cover much of 18th century knowledge of vertebrate anatomy, but the work came to an abrupt end with the advent of the French Revolution to which he did not survive. Vicq d'Azyr died in 1794 at age $46 .^{6}$

\section{Nigral neurons: the very first images}

In 1865, the French psychiatrist and neuroanatomist JulesBernard Luys (1828-1897), who worked first at la Salpêtrière and then at la Charité hospital in Paris, ${ }^{8}$ published a copious treatise entitled Recherches sur le système cérébro-spinal in which he made significant contributions to human brain anatomy. ${ }^{9}$ His book contained the very first identification of the subthalamic nucleus, which was commonly referred to as Luys's body or corpus Luysii during more than a century. ${ }^{8}$ Luys

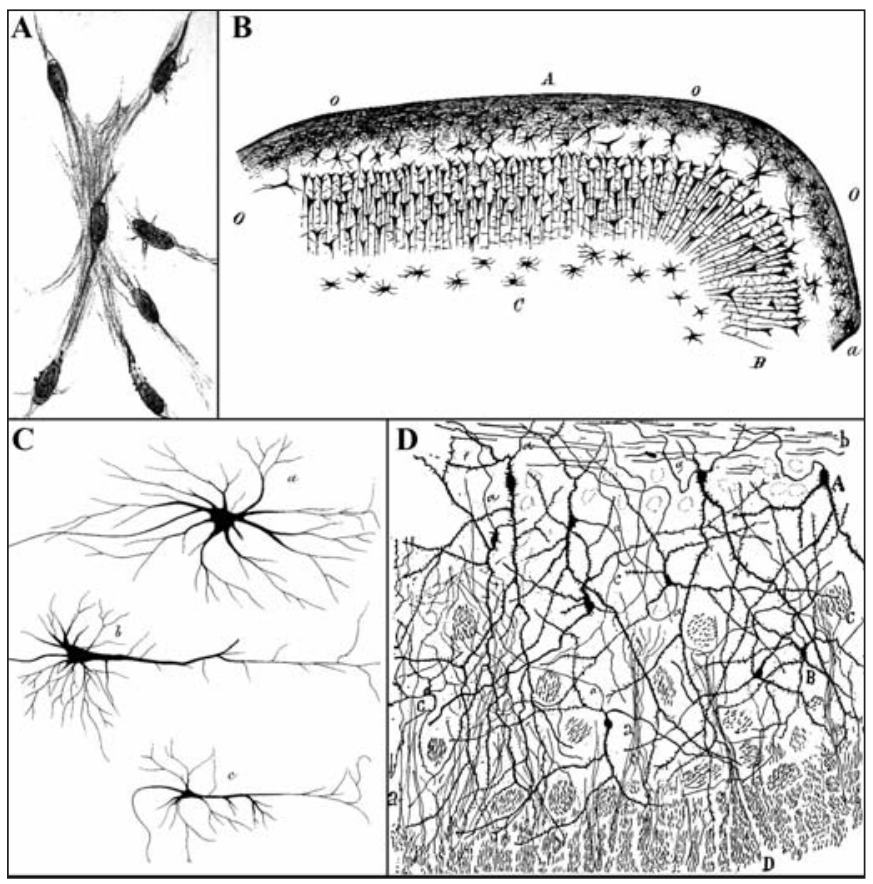

Figure 2: Nigral neurons: the very first images. A: Reproduction of a figure (plate XIX) from Luys JB. Recherches sur le système cérébrospinal. Paris: Baillière, 1865. It illustrates some neurons of the human substantia nigra endowed with long processes that merge within one another so as to form a reticulum. B,C: Reproduction of two drawings (plate I) from Mingazzini G. Sulla fine struttura della Substantia nigra Sömmeringii. Roma: Reale Academia dei Lincei, 1888. The figure in B offers a general view of the human substantia nigra, as seen in coronal section. The structure is shown here upside down, that is, the ventral border of the cerebral peduncle is at the top and its medial border on the right. The figure in $C$ provides some examples of the various types of pyramidal cells encountered in the dorsal layer of human substantia nigra. D: Reproduction of a figure from Ramón y Cajal S. Histologie du système nerveux de l'homme et des vertébrés. Vol. 2. Madrid: Consejo Superior de Investigationes Scientificas, 1911. It shows a coronal section through the substantia nigra of a few-day-old kitten stained with the Golgi method. The cerebral peduncle is at the bottom (marked " $D$ ") and the letters " $B$ " and " $A$ " indicate neurons of the inferior (pars reticulata) and superior (pars compacta) zones, respectively. 
extensively used the microscope to unravel the cellular organization of the various components of the basal ganglia and provided what appears to be the very first images of nigral neurons. ${ }^{9}$ He underlined the numerous and densely packed nigral neurons with ovoid or polygonal perikarya from which emerged numerous elongated processes (Figure 2A). He also noted that nigral neurons stained intensely because they contained dark pigments. Luys depicted nigral neurons having long processes that literally merged within one another, a detail that betrayed his acceptance of the then commonly held reticularist view of the organization of the central nervous system. ${ }^{9}$ Luys commonly referred to the substantia nigra as the locus niger de Sœmmering [sic] and, in doing so, contributed to the perennial nomenclature confusion alluded to above.

More than twenty years after Luys' pioneering work, the Italian neuroanatomists Giovanni Mingazzini and Domenico Mirto and the Japanese morphologist Torata Sano provided more detailed descriptions of nigral neurons. In 1888, Mingazzini described the human substantia nigra as a highly stratified structure composed of a dorsal layer containing several types of pyramidal cells and a ventral layer harboring "atypical" cells (Figure 2B, C).$^{10} \mathrm{He}$ specified that pyramidal cells had a cylinder-axis (axon) that coursed forward within the midbrain tegmentum. Mirto was the first to note, in 1896, the close morphological resemblance between neurons of the substantia nigra and those of the globus pallidus, another important component of the basal ganglia. ${ }^{11} \mathrm{He}$ also recognized that the vast majority of nigral neurons were Golgi type I cells (projection neurons).

In 1910, Sano reported the results of an extensive comparative study of the substantia nigra in a wide range of species, including man, and provided a detailed description of nigral neurons. ${ }^{4}$ Sano subdivided the substantia nigra into a pars compacta, harboring a densely packed population of pigmented neurons, and a pars reticulata, containing a smaller number of non-pigmented neurons that were rather loosely scattered within a dense fiber meshwork. This nigral subdivision, still in use today, was largely based on an earlier suggestion made by Ramón y Cajal (1852-1934) in his pioneering description of the substantia nigra published in $1899 .{ }^{12}$ Using the Golgi staining procedure, Cajal provided a clear depiction of the different types of neurons that populated each of the two major portions of the substantia nigra that he called superior and inferior zones (Figure 2D). He also emphasized the existence of long and dorsoventrally oriented dendritic bundles that emerged from the large pyramidal-shaped neurons located within the superior zone (pars compacta) of the substantia nigra. Despite the quality of the material he had in hand, Cajal was unable to trace the axonal projection of nigral neurons, except for small distances within the midbrain tegmentum. Cajal underlined the confusion that existed over the issue of nigral efférents and indicated that the Russian neurologist Vladimir Bechterev (1857-1927) was the only one at that time who believed that nigral neurons projected their axons as far rostrally as the striatum. ${ }^{12}$

\section{Substantia nigra involvement in Parkinson's disease: early evidence from la Salpêtrière}

Jean-Martin Charcot (1825-1893) and his colleagues at la Salpêtrière hospital in Paris (Figures 3A, B) contributed

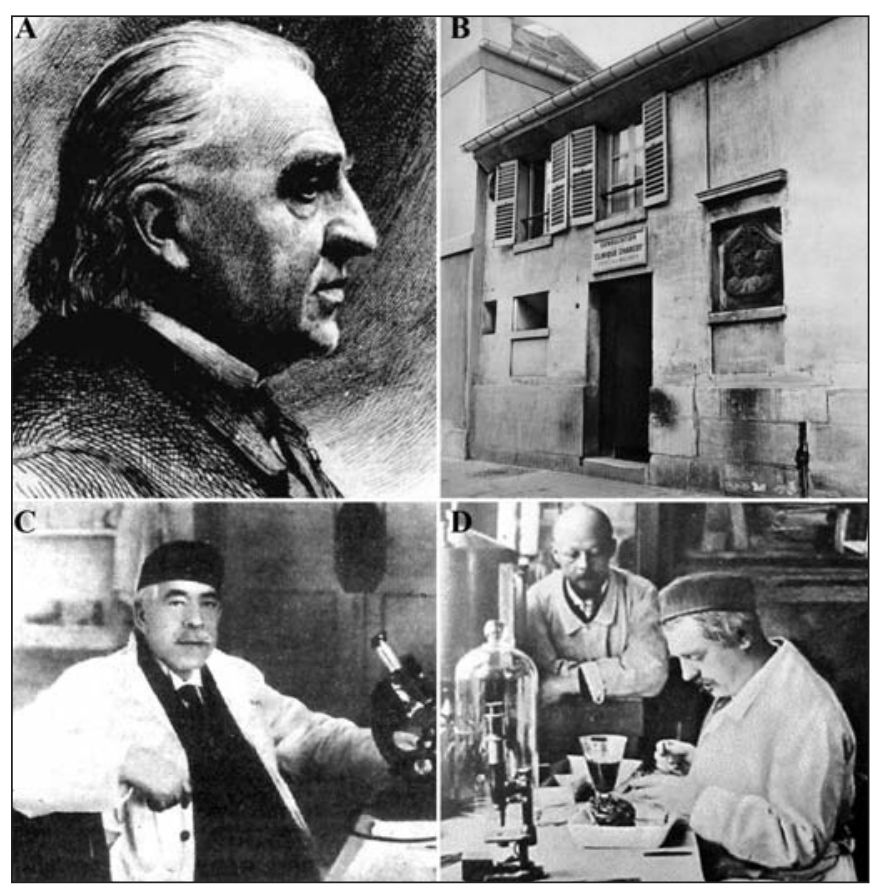

Figure 3: La Salpêtrière's contribution to Parkinson's disease. A: JeanMartin Charcot in his sixties. B: Patients' entrance at Charcot's clinic located in the Paniset Division at la Salpêtrière. C,D: Georges Marinesco $(C)$ and Edouard Brissaud $(D)$ at work in their laboratory at la Salpêtrière (from Université Pierre-et-Marie-Curie/SCDM/ Bibliothèque Charcot, Paris).

significantly to our knowledge of Parkinson's disease. Charcot's enlightening clinical description of Parkinson's disease greatly helped to single out this affection from other tremor-associated neurological disorders, particularly multiple sclerosis. ${ }^{13,14}$ The various clinical features whereby Parkinson's disease can be distinguished from multiple sclerosis were first described in a thesis entitled Sur la paralysie agitante et la sclérose en plaques généralisée published in 1868 by Leopold Ordenstein (18351901), a young German neurologist who worked at la Salpêtrière under Charcot's supervision. ${ }^{15}$ Charcot recognized the four major symptoms of Parkinson's disease: tremor, bradykinesia, rigidity and balance impairment. Although tremor was a cardinal feature of Parkinson's disease, Charcot insisted that it was not necessarily present in all parkinsonian patients and, although he praised James Parkinson's pioneering description of the disease, ${ }^{1}$ he argued that the term paralysis agitans that Parkinson used in his 1817 essay was improper and suggested it be changed to "Parkinson's disease". Charcot emphasized the importance of rigidity as a parkinsonian sign and distinguished it from pyramidal and spinal spasticity. He did not speak specifically of akinesia, but clearly recognized it as distinct from rigidity; he pointed out that one of the major problems in Parkinson's disease was the slowness in execution of movement. In regards to gait deficits, Charcot was fascinated by parkinsonian patients' tendency to propulse or retropulse as they waked, as if they "ran 

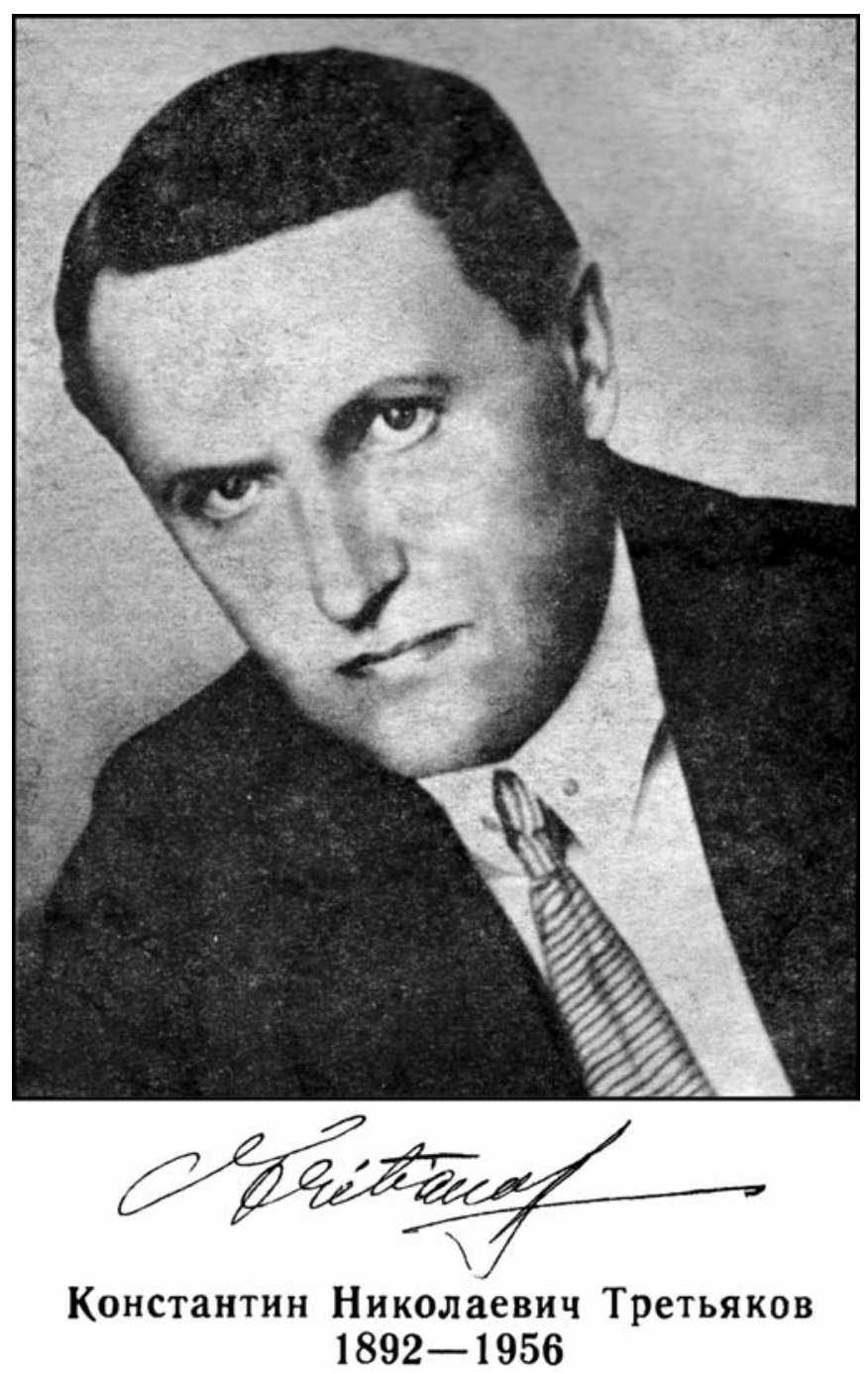

Figure 4: Constantin Trétiakoff in his 50's. Trétiakoff's signature appeared in dedicated copy of his thesis available at Charcot's library in Paris; it was digitalized and electronically imported upon the portrait, which was kindly provided by Dr. Marianna Selikhova, The National Hospital for Neurology and Neurosurgery, Queen Square, London, UK.

after their center of gravity." 16 Charcot was also the first to describe the masked facies and writing problems associated with Parkinson's disease. He introduced treatment with the anticholinergic alkaloid drug hyoscyamine derived from the plant Atropa belladonna. This anticholinergic therapeutic approach, which was alluded to for the first time in Ordenstein's 1868 thesis, ${ }^{15,17}$ remained in use, in various modified forms, until the advent of levodopa therapy a century later. ${ }^{16-18}$ Although Charcot used the anatomo-clinical method, which correlated distinct neurological symptoms in living patients with specific brain lesions at autopsy, he failed to discover the main pathological hallmark of Parkinson's disease, which he considered a névrose, that is, a neurological disorder without known pathological lesion. ${ }^{16}$
Charcot's efforts to elucidate the physiopathology of Parkinson's disease were actively pursued by some of his students, principally Georges Marinesco (Gheorghe Marinescu, 1863-1938) and Edouard Brissaud (1852-1919). While working at la Salpêtrière, the Romanian neurologist Marinesco (Figure 3C) became acquainted with some of Charcot's former students, particularly Pierre Marie (1853-1940), and it is in Marie's service that Marinesco initiated a fruitful collaboration with the pathologist Paul Oscar Blocq (1860-1896). In 1892, Blocq and Marinesco discovered small deposits of degenerating neurites scattered within the grey matter of epileptic patients; this was the first description of what is known today as senile plaques. ${ }^{19} \mathrm{~A}$ year later, they reported evidence that a lesion of the substantia nigra might cause parkinsonian tremor. ${ }^{20}$ This suggestion emerged from the study of a single patient, a 38-year-old man suffering from tuberculosis and admitted in Charcot's ward because he was showing signs of Parkinsonism, principally muscular rigidity and tremor on the left side of the body. At la Salpêtrière, Jean-Baptiste Charcot (1867-1936), the son of the famous neurologist, took care of the patient. He carefully documented the evolution of the disease and made, at different points in time, several recordings of the patient's tremor that were used by Blocq and Marinesco in their 1893 paper. ${ }^{20}$ JeanBaptiste Charcot's final diagnostic was that of a typical unilateral Parkinsonism. The patient died of pulmonary complications and

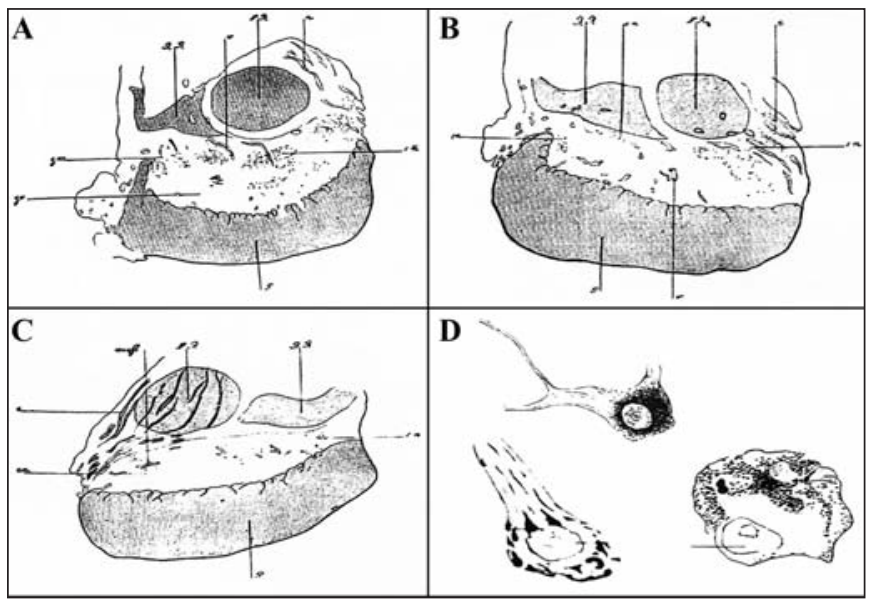

Figure 5: Substantia nigra lesions in Parkinsonism. Reproduction of some figures (plate 1, figs 1 and 2; plate III, fig. 6; plate IV, figs 1, 2 and 9) from Trétiakoff C. Étude de l'anatomie pathologique du locus niger de Sommering. Paris: Jouve, 1919. A-C: Topographic illustrations of the substantia nigra in a 80-year-old patient suffering from senile dementia without signs of Parkinsonism (A), a patient who was afflicted by idiopathic Parkinson's disease (B), and a patient who suffered from postencephalitic Parkinsonism (C), as seen in the coronal plane. Note the marked loss of pigmented nigral neurons in the two parkinsonian patients compared to the senile individual. D: Microscopic depictions of nigral pigmented neurons undergoing "grumous" degeneration in parkinsonian patients. An unaffected neuron is shown in the upper left, whereas a neuron displaying signs of neurofibrillary fragmentation is depicted in lower left. The neuron on the right is in a more advanced stage of degeneration and it exhibits Lewy bodies. 
at autopsy an enucleated tuberculoma the size of a hazelnut ("une noisette") was found at the basis of the midbrain. The corticospinal tract, superior cerebellar peduncle and cerebral peduncle being relatively spared by the tumor, the authors concluded that the tremor-inducing tuberculoma affected principally the substantia nigra. ${ }^{20}$

This important finding led Edouard Brissaud (Figure 3D), who took over Charcot's teaching at la Salpêtrière, to postulate that the substantia nigra was involved in the control of muscle tone and that a lesion of this structure caused Parkinson's disease. In a lecture that was given at la Salpêtrière, in 1893, and faithfully recorded and published by his colleague Henri Meige (1866-1940) in 1895, Brissaud clearly stated that a lesion of the substantia nigra might well be the anatomical substratum of Parkinson's disease. ${ }^{21}$ Despite these insights, little attention was paid to the substantia nigra during the 20 years that followed Blocq, Marinesco and Brissaud's contributions. Most neuropathological investigations of Parkinson's disease during the first two decades of the 20th century focused on the striatum and some of the major output pathways of the basal ganglia, particularly the ansa lenticularis and the lenticular fasciculus.

\section{Trétiakoff's convincing demonstration}

A confirmation of Brissaud's hypothesis came from the work of Constantin Trétiakoff (Konstantin Nicolaevich Tretiakoff, 1892-1956), a young Russian emigrant who, from 1917 until about 1920, worked as Head of the laboratory of the nervous diseases clinic in Pierre Marie's service at la Salpêtrière. At that time, the First World War (1914-1918) was coming to an end, but mankind had to struggle against the encephalitis lethargica pandemic, which had led to a marked increase in the numbers of cases of Parkinsonism being seen in neurological practice. ${ }^{22}$ The Austrian neuropsychiatrist Constantin von Economo (Constantin Alexander Economo Freiherr von San Serff, 1876-1931), who spent some training time in Pierre Marie's service at la Salpêtrière in 1913, was the first to draw attention to the parkinsonian signs often associated with lethargic encephalitis, the sleepy sickness that now bears his name. ${ }^{23}$

In that context, Trétiakoff (Figure 4) had ample opportunities to satisfy his keen interest for neuropathology by examining brain material from cases of Von Economo's disease and comparing them with those of parkinsonian patients. Most of his work was done in the laboratory of Marinesco, who played an important role in orienting the young Trétiakoff's research toward the physiopathology of Parkinsonism. In 1919, Trétiakoff successfully defended a doctoral thesis entitled Anatomie pathologique du locus niger de Sxmmering [sic], in which he reported the results of a detailed neuropathological study of the substantia nigra in 54 brains, nine of which had Parkinson's disease and three post-encephalitic Parkinsonism. ${ }^{24}$ Compared to age-matched individuals without signs of Parkinsonism (Figure 5A), Trétiakoff noted in all Parkinson's disease cases he examined a marked loss of pigmented nigral neurons (Figure 5B) with swelling of cell bodies, grumous degeneration (dégénérescence grumeleuse) and neurofibrillary alterations (Figure 5D). Some of the surviving nigral neurons were found to harbor typical neuronal deposits that Trétiakoff named corps de Lewy in recognition of the German neuropathologist Friedrich Heinrich Lewy (1885-1950), who first detected these cyto-

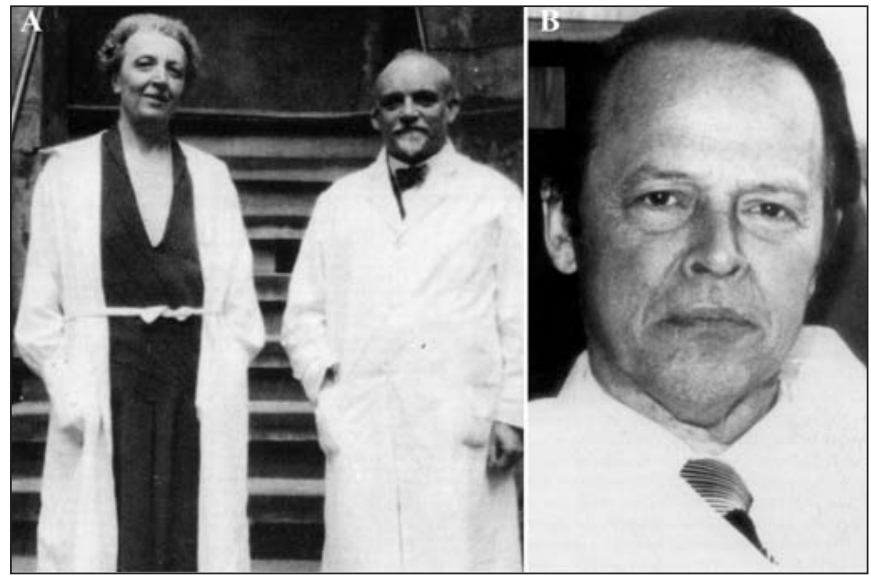

Figure 6: German contribution to the physiopathology of Parkinsonism. A: Cécile and Oskar Vogt on the steps of the Kaiser-Wilhelm-Institut für Hirnforschung at Berlin-Buch in the early 1930s. B: Rolf Hassler while he was Head of the Max-Plack-Institut für Hirnforschung at Frankfurt am Main in the early 1970s. Dr. Edward G. Jones, Center for Neuroscience, University of California, Davis, kindly provided the photographs.

plasmic inclusions in the dorsal nucleus of the vagus nerve and substantia innominata of parkinsonian patients. ${ }^{25}$ Trétiakoff found severe devastation of the substantia nigra with hyaline and granular degeneration in the few surviving cells in cases of von Economo's disease (Figure 5C). He also noted the presence of inflammatory infiltrations around blood vessels and in the parenchyma of the nigral tissue in cases of both Parkinson's disease and post-encephalitic Parkinsonism, but did not comment further on the functional significance of this finding. Trétiakoff thought that the substantia nigra lesions he observed in Parkinson's disease could also occur in various other disorders characterized by disturbances of muscular tone, including spasmodic torticollis and chorea. He concluded his thesis by saying "Hence, the results of our research lead us to think there exist intimate relationships between the substantia nigra and Parkinson's disease. These relations are very likely that of a cause and its effects" (Ainsi donc, les résultats de nos recherches nous amènent à dire que, entre les lésions du Locus niger et la maladie de Parkinson, existent des relations très intimes. Il $s$ 'agit très probablement de relations de cause à effet). ${ }^{24}$

Trétiakoff's first incursion into the field of medical research was, to say the least, highly fruitful. However, the young researcher did not probably fully realize that his contribution would ultimately be considered as one of the most important neuropathological findings of the 20th century. ${ }^{22}$ After 1919, Trétiakoff actively collaborated with Marinesco on a histopathological study of Friedreich ataxia, which revealed the specific lesions of the lateral corticospinal tract, posterior columns and dorsal root ganglia that characterized this inherited motor disorder. ${ }^{26}$ Despite his major contribution to French neuropathology, Trétiakoff was unable to obtain a permanent position in the service of the despotic Pierre Marie at la Salpêtrière or elsewhere in Paris. He left France in 1921 and, 
after a long detour through Brazil, he went back to Russia where he became Head of the new Department of Neuropathology at the Saratov Medical Institute. Trétiakoff spent the rest of his working life in Saratov, a small academic town located along the shores of the Volga some $1000 \mathrm{~km}$ southwest of Moscow, and never lost his keen interest in the physiopathology of Parkinson's and von Economo diseases. ${ }^{22}$

\section{A confirmation from Germany}

Although it reported evidences that would be considered as highly convincing by today standards, Trétiakoff's work raised considerable doubts among his colleagues, who rejected the idea that lesions of a brain structure as small as the substantia nigra might cause motor disorders as massive as those encountered in Parkinson's disease. The neurologist Jean Lhermitte (1877-1959) and the pathologist Lucien Cornil (1888-1952), among others, claimed that the most consistent lesions they could observed in Parkinsonism were those that affected the cerebral cortex and further stated they had found marked nigral losses in the brain of some patients that had no clinical history of Parkinsonism. ${ }^{27}$ In contrast, Charles Foix (1882-1927) and Jean Nicolesco (18951957) presented data that concurred with Trétiakoff's findings. In their influential monograph on the basal ganglia published in $1925,{ }^{28}$ they acknowledged that the substantia nigra in parkinsonian patients showed prominent changes, including neuronal atrophy, vacuolation, neurofibrillary alterations and cytoplasmic inclusions of the Lewy body type. They also noted similar changes in the locus coeruleus, the pigmented cells of the dorsal nucleus of the vagus nerve and the substantia innominata. ${ }^{28}$

Although most investigators agreed that nigral lesion was the major pathological hallmark of Parkinsonism associated with von Economo's disease, many contemporary neurologists were hesitant to accept the idea that the same was true for idiopathic Parkinson's disease. At that time, the most important lesions in Parkinson's disease were believed to be those that targeted the major input and output structures of the basal ganglia, that is, the striatum and the globus pallidus. Amongst the most prominent advocates of this view of the physiopathology of Parkinson's disease were Oskar Vogt (1870-1959) and his wife Cécile Mugnier-Vogt (1875-1961), two highly praised neuroanatomists who were instrumental in the creation of the Kaiser-WilhelmInstitut für Hirnforschung at Berlin in the 1930s (Figure 6A). It was nevertheless in the Vogts' laboratory that, just before the Second World War, a young doctoral student by the name of Rolf Hassler (1914-1984) elucidated in unprecedented detail the neuropathology of Parkinson's disease and post-encephalitic Parkinsonism. ${ }^{29}$ Hassler's post-mortem study revealed that the striatum and the globus pallidus were largely unaltered in Parkinson's disease or post-encephalitic Parkinsonism, whereas dense clusters of neurons in the ventral part of the substantia nigra pars compacta, which he termed Spedd and Spezz, were severely affected with surviving cells containing numerous Lewy bodies. ${ }^{29}$ These findings shed serious doubts on the Vogts' beliefs, while confirming and extending Trétiakoff's seminal insights. Rolf Hassler (Figure 6B) later became director of MaxPlanck-Institut für Hirnforschung at Frankfurt am Main and, despite heavy administrative duties, never stopped working on the physiopathology of Parkinson's disease. He also provided the first comprehensive cytoarchitectonic description of the human thalamus, to which all modern studies continue to refer and became a leader in stereotaxic neurosurgery, an approach that was extensively used in the 1950s to alleviate some of the motor deficits, particularly tremor, encountered in Parkinson's disease.

\section{The dopaminergic hypothesis of Parkinson's disease and beyond}

The finding that dopamine is a specific chemical marker of nigral neurons that degenerate in Parkinsonism brought further evidence for the existence of a close relationship between the substantia nigra and Parkinson's disease. Detailed accounts of this important discovery have recently been provided by Arvid Carlsson (1923- ) and Oleg Hornykiewicz (1926- ), two of the main actors in this fascinating segment of the history of Parkinson's disease ${ }^{.30,31}$ The story began in the late 1950s with the demonstration by Carlsson and his colleagues in Sweden that dopamine is not only a metabolic precursor of noradrenalin but can also act as a neurotransmitter on its own. A few years later, Hornykiewicz and his coworkers in Austria discovered that dopamine is markedly depleted in the striatum of parkinsonian patients. At about the same time, the development of the histofluorescence method allowed Swedish investigators to detect the presence of dopamine in the vast majority of the substantia nigra pars compacta neurons and to trace their axonal projection to the striatum. ${ }^{30}$ Animal models of Parkinson's disease were also developed in the mid-1960s and their use greatly helped confirm that dopamine is conveyed toward the striatum through the nigrostriatal pathway. ${ }^{32}$ Degeneration of this pathway was shown to initiate a complex cascade of events responsible for the appearance of parkinsonian motor deficits, a notion that led to the development, in the late 1960s, of levodopa replacement therapy to alleviate some of the motor symptoms of Parkinson's disease. ${ }^{30-32}$

All these results support the notion that the lack of dopamine of nigral origin plays a central role in the pathogenesis of Parkinson's disease. It was progressively discovered, however, that many later-stage features of Parkinsonism are less responsive to levodopa and this treatment is often accompanied by deleterious side effects such as motor fluctuations and dyskinesia. This led to the development of new therapeutic approaches that are no longer centered upon the substantia nigra or the dopaminergic nigrostriatal pathway. Prominent among these novel approaches is high frequency electrical stimulation (deep brain stimulation) of the internal segment of globus pallidus or subthalamic nucleus, which improves levodoparesponsible symptoms and provides a proper management of motor fluctuations and dyskinesia. ${ }^{33}$

The picture becomes even more complex when the intricate relationship between dopamine and other neurotransmitters at basal ganglia level and the multifaceted organization of the nigrostriatal dopaminergic pathway are taken into account. The nigrostriatal dopaminergic pathway interacts with several other chemospecific neuronal systems that target the striatum, including the serotoninergic projections from midbrain raphe nuclei and the massive glutamatergic afferents from the thalamus and cerebral cortex. ${ }^{34}$ Cholinergic neurons of the basal forebrain are also involved in Parkinson's disease, particularly in parkinsonian patients with cognitive and memory deficits. ${ }^{35} \mathrm{On}$ 
the other hand, single-axon tracing studies indicate that nigrofugal dopaminergic projections form a widely distributed and highly collateralized neuronal system. Far from being a monolithic entity, this complex network appears to be composed of several subsystems, each having a distinct origin in the substantia nigra, a specific and non-overlapping termination site in the basal ganglia and a different degree of vulnerability to the neurodegenerative mechanisms at play in Parkinson's disease. ${ }^{34}$ For example, axons emerging from neurons located in the dorsal tier of the substantia nigra pars compacta arborize profusely within the internal segment of the globus pallidus. This nigropallidal system, which is less prone to degeneration than the nigrostriatal projection, might play an important role in the pathogenesis of Parkinson's disease because it allows dopamine to directly act upon basal ganglia output neurons. These findings underline the far-reaching effects of substantia nigra lesions in Parkinson's disease, which can no longer be considered as a simple dopamine deficiency disorder nor as a single neurological syndrome.

\section{ACKNOWLEDGEMENTS}

The authors thank Mrs. Doris Côté for expert handling of the illustrations and Mrs. Véronique Leroux-Hugon for giving us access to Charcot's personal library at la Salpêtrière, Paris.

\section{REFERENCES}

1. Parkinson J. An essay on the shaking palsy. London: Sherwood, Neely and Jones; 1817.

2. Sœmmerring ST. De basi encephali et originibus nervorum cranio egredientium libre quinque. Göttingen: Vandenhoeck Widow; 1778 .

3. Sœmmerring ST. De basi encephali et originibus nervorum cranio egredientium libre quinque. In: Ludwig CF, editor. Scriptores neurologici minores selecti sive opera minora ad anatomiam physiologiam et pathologiam nervorum spectantia, vol. 2 . Leipzig: Junius; 1792. p. 1-112.

4. Sano T. Beitrag zur vergleichenden Anatomie der Substantia nigra, des Corpus Luysii und der Zona incerta. Mschr Psychiat Neurol. 1910; 27: 110-27.

5. Faull RLM, Taylor DW, Carman JB. Sœmmerring and the substantia nigra. Med Hist. 1968; 12: 297-9.

6. Parent A. Félix Vicq d'Azyr: anatomy, medicine and revolution. Can J Neurol Sci. 2007; 34: 30-7.

7. Vicq d'Azyr F. Traité d'anatomie et de physiologie avec des planches coloriées représentant au naturel les divers organes de l'homme et des animaux. Paris: Didot l'Aîné; 1786.

8. Parent A, Parent M, Leroux-Hugon V. Jules Bernard Luys: a singular figure of 19th century neurology. Can J Neurol Sci. 2002; 29: 282-8

9. Luys JB. Recherches sur le système cérébro-spinal, sa structure, ses fonctions et ses maladies. Paris: Baillière; 1865.

10. Mingazzini G. Sulla fine struttura della Substantia nigra Sömmeringii. Reale Academia dei Lincei (Roma). 1888; 5: 36-40.

11. Mirto D. Sulla fina anatomia delle regioni peduncolare e subthalamica nell' uomo. Rivista di Patologia nervosa e mentale (Firenze). 1896; 1: 57-60

12. Ramón y Cajal S. Textura del sistema nervioso del hombre y de los vertebrados (3 vols). Zaragoza: Gobierno de Aragón; 1899. [French trans. by Azoulay L. Histologie du système nerveux de l'homme et des vertébrés (2 vols). Madrid: Consejo Superior de Investigationes Scientificas; 1909, 1911].

13. Charcot JM, Vulpian A. La paralysie agitante. Gaz Hebdom Med Chir. 1861; 8: 765-8, 816-23.

14. Charcot JM. De la paralysie agitante (leçon 5). Euvres complètes. Progrès Médical (Paris). 1869; 1: 161-88.
15. Ordenstein L. Sur la paralysie agitante et la sclérose en plaques généralisée. Paris: Delahaye; 1868.

16. Goetz CG. Charcot on Parkinson's disease. Mov Dis. 1986; 1: 27-32.

17. Lehmann HC, Hartung HP, Kieseier BC. Leopold Ordenstein: on paralysis agitans and multiple sclerosis. 2007; 13: 1195-9.

18. Sourkes TL. 'Rational hope' in the early treatment of Parkinson's disease. Can J Physiol Pharmacol. 1999; 77: 375-82.

19. Blocq P, Marinesco G. Sur les lésions de la pathogénie de l'épilepsie essentielle. Sem Med. 1892; 12: 445-6.

20. Blocq P, Marinesco G. Sur un cas de tremblement parkinsonien hémiplégique symptomatique d'une tumeur du pédoncule cérébral. C R Soc Biol. 1893; 5: 105-11.

21. Brissaud E. Nature et pathogénie de la maladie de Parkinson. In: Meige H, editor. Leçon sur les maladies nerveuses (Salpêtrière, 1893-1894). Vol. 1, leçon 23. Paris: Masson; 1895. p. 488-501.

22. Lees AJ, Selikhova M, Andrade LA, Duyckaerts C. The black stuff and Konstantin Nicolaevich Tretiakoff. Mov Dis. 2008; 23: 777-83.

23. von Economo C. Encephalitis lethargica. Wiener klinische Wochenschrift. 1917; 30: 581-5.

24. Trétiakoff C. Contribution à l'étude de l'anatomie pathologique du locus niger de Sœmmering avec quelques déductions relatives à la pathogénie des troubles du tonus musculaire et de la maladie de Parkinson. Paris: Jouve; 1919.

25. Lewy FH. Paralysis agitans. I. Pathologische Anatomy. In: Lewandowsky M, editor. Handbuch der Neurologie, Vol. III, spez Neurol II. Berlin: Springer; 1912. p. 920-33.

26. Marinesco G, Trétiakoff C. Étude histopathologique des centres nerveux dans trois cas de maladie de Friedreich. Rev Neurol (Paris). 1920; 27: 113-31.

27. Lhermitte J, Cornil L. Recherches anatomiques sur la maladie de Parkinson. Rev Neurol (Paris). 1921; 28: 587-92.

28. Foix C, Nicolesco J. Anatomie cérébrale. Les noyaux gris centraux et la région mésencéphalo-sous-optique; suivi d'un appendice sur l'anatomie pathologique de la maladie de Parkinson. Paris: Masson; 1925.

29. Hassler R. Zur Pathologie der Paralysis agitans und des postenzephalitischen Parkinsonismus. J Psychol Neurol. 1938; 48: 387-476.

30. Carlsson A. Treatment of Parkinson's with L-DOPA. The early discovery phase, and a comment on current problems. J Neural Transm. 2002; 109: 777-87.

31. Hornykiewicz O. Basic research on dopamine in Parkinson's disease and the discovery of the nigrostriatal dopamine pathway: the view of an eyewitness. Neurodegenerative Dis. 2008; 5: 1147.

32. Poirier LJ, Sourkes TL. Influence of the substantia nigra on the catecholamine content of the striatum. Brain. 1965; 88: 181-92.

33. Benabid AL, Chabardes S, Mitrofanis L, Polack P. Deep brain stimulation of the subthalamic nucleus for the treatment of Parkinson's disease. Lancet Neurol. 2009; 8: 67-81.

34. Parent M, Parent A. Relationship between axonal collateralization and neuronal degeneration in basal ganglia. J Neural Transm. 2006; 70: 85-8

35. Whitehouse PJ, Hedreen JC, White CL 3rd, Price DL. Basal forebrain neurons in the dementia of Parkinson disease. Ann Neurol. 1983; 13: 243-8. 